\title{
INTERNAL AND EXTERNAL FACTOR INFLUENCE ICT ADOPTION: A CASE of INDONESIAN SMES
}

\author{
Lucy Chairoel $^{{ }^{*},}$, Tri Rachmat Riski ${ }^{2}$ \\ ${ }^{12}$ Faculty of Economic and Business, Dharma Andalas University \\ Sawahan Street Padang West Sumatera 25157, Indonesia \\ *Corresponding author; Email: lucy.chairoel69@gmail.com
}

\begin{abstract}
The using of Information Communication Technology (ICT) in the industry is growing fast. Nevertheless, Small Medium Enterprises (SMEs) in Indonesia do not follow these conditions. The influencing factor of ICT adoption has been identified as internal and external factors. Accordingly, the objective of the study is to identify the influence factor of using ICT adoption in Indonesian SMEs. The conceptual model in this study was the combination between Diffusion of Innovation (DOI) theory and The Technology-Organization-Environment (TEO) theory. The survey method for 146 SMEs selected conveniently in Indonesia. The distribution of data by online and data obtained is analysed using SEM/Smart-PLS program. The study has exogenous variable including technology, organization, managerial characteristic, and environment. The endogen variable is ICT adoption. The research found that ICT used was predicted by characteristic of management, organizational and technology.
\end{abstract}

Keywords: Technology, oganization, managerial characteristic, environment, ICT adoption.

\section{Introduction}

Nowdays, the use of Information Communication Technology (ICT) by enterprises cannot be ignored. Compared with SMEs, most ICT adoption is used by large companies. Over the past two decades, the using ICT by SMEs has generated a great deal of interest among researchers, governments, and international organizations (Kabongo \& Okpara, 2014). Many business organizations cannot avoid the development of ICT adoption. The previous studies have found the adoption of ICT in SMEs is still slow, it is because many factors affect it's especially in developing countries (Muafi \& Roostika, 2014). Although many barriers to widespread adoption of ICT in SMEs in developing countries but SMEs started receiving ICT adoption (Ndiege, Herselman. \& Flowerday, 2012; Chairoel, Widyarto, \& Pujani, 2015). Previous studies have shown internal and external factors affecting the use of ICT (Chong, 2008; Kapurubandara, 2009, Ghobakhloo, Amado \& Arias-Aranda, 2011a; Awa, Ojiabo, \& Emecheta, 2015). Internal factors consist of technological, organizational and managerial characteristics, while external factor is environment. Managerial characteristic in this study explain about people to make decision in SMEs just like an owner, Chief Executive Officer (CEO) or top manager. The number of study stated that the individual characteristic crucial role in implementation of new technology (Bayo-Moriones \& Lera-López, 2007; Gangwar, Date, \& Ramaswamy, 2015). Some study found the positive impact knowledge CEO and expe- rience that influence of ICT in SMEs (Ghobakhloo et al., 2011a). Additionally the attitude of CEO (top manager) or owners influenced the use of ICT (Golding, Donaldson, Tennant \& Black, 2008; Maryeni, Govindaraju, Prihartono, \& Sudirman, 2014). The environment has a strong impact of the decision to adopt ICT (Bayo-Moriones \& Lera-López, 2007). The role of government is important to the development of the use ICT in SMEs. Beside the government, supplier and customers the factors of environment whereas effect the adoption of ICT. Customer and supplier of pressure will force SMEs to use ICT in order to improve the marketing of its product. The number of study showing government support for ecommerce (Tigre, 2003; Looi, 2005; Jeon, Han, \& Lee, 2006; Chong, 2008; Huy, Rowe, \& Truex, 2012; Ahmad, Bakar, Faziharudean, \& Zaki, 2015) and ICT adoption (Alam \& Noor, 2009; Irefin, Abdul-Azeez, \& Tijani, 2012) in various develop and developing countries. This is supported by Gemino, Mackay, and Reich (2006); they state that supplier and customer had a strong influence on IT adoption. According to previous study pressure from buyer and supplier seemed to be logical reason for adopting Electronic Data Interchange (EDI) (Al-qirim, 2007), e-commerce (Chong, 2008; Ghobakhloo et al., 2011b; Huy et al., 2012), and ICT adoption (Alam \& Noor, 2009). Another reason for small businesses to adopt Information Technology (IT) comes from government policy.

ICT adoption in Indonesian SMEs is still low caused by an internal and external factor. The Indone- 
sian SMEs is the first phase using information technology. A few studies examined the influence of the ICT adoption. Given the foregoing considerations, the research questions are proposed: what are the factors influence the use of ICT in Indonesian SMEs?

\section{ICT Adoption}

This study constructs the adoption of ICT in organizations focusing on the actual use of ICT such as the use of computers, internet access, communications as well as marketing. Actual use of ICT is shown in seeking information, taking orders, accept payment, customer service, purchase orders, payments to vendors (Bayo-Moriones, Billon, \& LeraLópez, 2013; Delone \& Mclean, 2004; Tan, Chong, Lin, \& Eze, 2010).

\section{The Relationship Technology factor and ICT adoption}

Technology is seen as a necessary measure for adoption when to adopt and use ICT. The decision to adopt the technology does not only depend on what is available in the market but how the technology according to the technology of the company (Rogers, 1995). Technologies are defined and presented in a variety of dimensions consisting of perceived relative advantage, compatibility, complexity, trialability, observability, cost investment and security (Ghobakhloo, Hong, Sabouri \& Zulkifli, 2011; Alam \& Noor, 2009).

$H_{l}$ : There is the significant relationship between technology factors and ICT adoption among Indonesian SMEs.

\section{The Relationship Organization Factor and ICT Adoption}

Organization factor is one important factor in the adoption of information technology addition technical factor (Azadegan \& Teich, 2010). Organizations can have different perspectives on how useful a technology may be. In using ICT adoption, it needs resources. In an enterprise, the most important resources to adopt the new technology consist of finance, human, technology resources. Especially for SMEs, if the managers consider that the importance of ICT adoption must be followed by the resources of the enterprise.

$\mathrm{H}_{2}$ : There is the significant relationship between organization factors and ICT adoption among Indonesian SMEs.

\section{The Relationship Managerial Characteristic and ICT Adoption}

Managerial characteristic in this study explain about people to make decision in SMEs just like an owner, Chief Executive Officer (CEO) or top manager (Golding et al., 2008; Ghobakhloo et al., 2011a). The previous study explained link between the attitude of the CEO toward IT and succesful application of IT (Huy et al., 2012). Manager has knowledge of IT to adopt of e-commerce (Thong \& Yap, 1995).

$H_{3}$ : There is the significant relationship between managerial characteristic factors and ICT adoption among Indonesia SMEs.

\section{The Relationship Environment and ICT Adoption}

Environment is something that outside an organization and cannot be controlled such as government, customer, and supplier pressure. The role of government is important to the development of the use ICT in SMEs. Beside the government, supplier and customers the factors of environment whereas effect the adoption of ICT. Customer and supplier of pressure will force SMEs to use ICT in order to improve the marketing of its product (Looi, 2005; Irefin et al., 2012).

The number of study showing government support for e-commerce (Chong, 2008; Huy et al., 2012; Jeon et al., 2006; Looi, 2005; Tigre, 2003) and ICT adoption (Alam \& Noor, 2009; Irefin et al., 2012) in various develop and developing countries. This is supported by Gemino et al. (2006); they state that supplier and customer had a strong influence on IT adoption.

According to previous study pressure from buyer and supplier seemed to be logical reason for adopting Electronic Data Interchange (EDI) (Al-Qirim, 2007), e-commerce (Chong, 2008; Ghobakhloo et al., 2011b; Huy et al., 2012), and ICT adoption (Alam \& Noor, 2009). Another reason for small businesses to adopt Information Technology (IT) comes from government policy.

$\mathrm{H}_{4}$ : There is the significant relationship between environment factors and ICT adoption among Indonesian SMEs.

\section{Research Method}

\section{Population and Sample}

This study made use of the deductive approach and an explanatory study indicated by the quantitative method. The source data in this study was primary data, collected from a SMEs owner, manager, or IT 
manager. They worked in SMEs. The sample of this study is the SME of four provinces in Indonesia (DKI Jakarta, West Java, East Java and Central Java). The criteria of this sample is the SMEs using ICT. The techniques of sampling used convenience sampling. Finally, there are 146 respondents at the initial study. The collecting data is by online via e-mail (electronic mail). The process gathering of SME email is by using www.indonetwork.co.id and www.bisnisukm. com. The questionery distributed by www.my3q. com.

\section{Method of data analysis}

The data analysis is conducted by employing Structural Equation Modelling (SEM) using Smart PLS program (Partial Least Square). In SEM process, Model and Structural Measurement was conducted by formative measurement model.

\section{Result and Discussion}

\section{Respondent Characteristic}

Respondents by gender were indicating the number of male $(73 \%)$ more rather than female (27\%). Respondents by age, the majority of respondents aged less than 40 years old $(64 \%)$. Around $78 \%$, the respondents by the position in organization are as an owner, manager, an owner and manager. The level of education of respondents' majority educated to bachelor degree (47\%). About $69 \%$, the number of employment of respondents was as much as between 5 until 15 employments. Out of the 146 SMEs responding in this study, the majority (69\%) were in service and trading. Moreover $61 \%$ of respondents had an income more than 100 million annual.

Table 1

Formative Measurement Model

\begin{tabular}{lccccc}
\hline & $\begin{array}{c}\text { Outer } \\
\text { Weight }\end{array}$ & T Stat & $\begin{array}{c}\text { Outer } \\
\text { Loading }\end{array}$ & T Stat & VIF \\
\hline \multicolumn{5}{c}{ TECHNOLOGY } \\
\hline PRA1 -> Technology & 0.29 & 1.85 & 0.53 & 3.86 & 1.09 \\
PRA2 -> Technology & 0.09 & 0.51 & 0.60 & 4.29 & 2.24 \\
PRA3 -> Technology & 0.02 & 0.09 & 0.60 & 3.80 & 2.32 \\
COM1 -> Technology & 0.09 & 0.40 & 0.66 & 4.96 & 1.86 \\
COM2 -> Technology & 0.29 & 1.52 & 0.58 & 4.74 & 1.74 \\
COM3 -> Technology & -0.14 & 0.65 & 0.30 & 2.36 & 1.44 \\
COM4 -> Technology & 0.05 & 0.28 & 0.59 & 4.02 & 1.83 \\
COM5 -> Technology & 0.01 & 0.04 & 0.51 & 3.97 & 1.57 \\
COP1 -> Technology & -0.20 & 1.01 & -0.20 & 1.82 & 2.07 \\
COP2 -> Technology & 0.09 & 0.37 & -0.22 & 1.89 & 3.05 \\
COP3 -> Technology & 0.20 & 0.73 & -0.22 & 1.84 & 4.56 \\
COP4 -> Technology & -0.19 & 0.44 & -0.23 & 1.80 & 5.35 \\
COP5 -> Technology & -0.04 & 0.12 & -0.18 & 1.51 & 4.42 \\
TR1 -> Technology & 0.08 & 0.33 & 0.32 & 2.80 & 1.75 \\
TR2 -> Technology & -0.10 & 0.43 & 0.46 & 3.78 & 2.15 \\
TR3 -> Technology & 0.04 & 0.22 & 0.41 & 3.26 & 1.93
\end{tabular}

\begin{tabular}{|c|c|c|c|c|c|}
\hline R4 -> Technology & & & & & \\
\hline TR5 -> Technology & -0.11 & 0.71 & 0.03 & 0.28 & 36 \\
\hline TR6 -> Technology & 0.08 & 0.48 & -0.19 & 1.53 & 34 \\
\hline OBS1 -> Technology & 0.25 & 0.98 & 0.77 & 5.80 & .57 \\
\hline OBS2 -> Technology & 0.03 & 0.14 & 0.68 & 4.50 & 31 \\
\hline OBS3 -> Technology & -0.15 & 0.66 & 0.65 & 4.65 & .81 \\
\hline OBS4 -> Technology & -0.03 & 0.09 & 0.68 & 4.59 & .53 \\
\hline OBS5 -> Technology & 0.14 & 0.52 & 0.70 & 5.58 & .53 \\
\hline OBS6 -> Technology & 0.10 & 0.44 & 0.62 & 4.68 & .04 \\
\hline OBS7 -> Technology & 0.16 & 0.83 & 0.64 & 5.91 & 23 \\
\hline CI1 -> Technology & -0.32 & 1.76 & -0.15 & 1.38 & .79 \\
\hline I2 -> Tech & 0.19 & 0.95 & 0.17 & 1.34 & .72 \\
\hline $\mathrm{CI} 3 \rightarrow \mathrm{T}$ & 19 & .87 & & 0.53 & 38 \\
\hline SEC1 - & -0.07 & 42 & -0.03 & 19 & 25 \\
\hline SEC2 -> & -0.18 & 1.05 & 0.34 & 30 & .24 \\
\hline SEC3 & 0.14 & .91 & 0.36 & 2.62 & .21 \\
\hline SEC4 & 0.14 & 0.89 & -0.01 & 0.03 & .21 \\
\hline \multicolumn{6}{|c|}{ ORGANIZATION } \\
\hline KW1 -> Or & -0.08 & 0.28 & 0.60 & 4.79 & 3.90 \\
\hline KW2 -> Or & 0.54 & 2.09 & 0.71 & .88 & 3.78 \\
\hline W3 $->$ Or & -0.27 & 1.17 & 0.53 & .55 & 2.69 \\
\hline $\mathrm{C} 1->\mathrm{Org}$ & 0.32 & 1.68 & 0.61 & 4.82 & 1.91 \\
\hline $\mathrm{C} 2>$ Org & 0.11 & 0.59 & 0.68 & 5.73 & 2.13 \\
\hline $\mathrm{C} 3->\mathrm{Or}$ & -0.08 & 0.38 & 0.65 & 5.44 & 1.77 \\
\hline $\mathrm{O} 1 \rightarrow \mathrm{O}$ & 0.22 & 0.73 & 0.76 & 7.49 & 1.64 \\
\hline tion & -0.04 & 0.22 & 0.65 & 5.77 & 2.28 \\
\hline SO3 -> & 0.01 & 0.04 & 0.68 & 85 & 2.10 \\
\hline tion & 0.21 & 0.95 & 0.77 & 51 & 2.37 \\
\hline ion & 0.25 & 1.00 & 0.73 & 57 & 2.25 \\
\hline L3 -> Organization & 0.14 & 0.59 & 0.74 & 5.36 & 2.76 \\
\hline \multicolumn{6}{|c|}{ MANAGERIAL CHARACTERISTIC } \\
\hline $\begin{array}{l}\text { AT1 -> Managerial } \\
\text { Charateristic }\end{array}$ & 023 & 145 & 80 & 7.70 & 261 \\
\hline $\begin{array}{l}\text { AT2 -> Managerial } \\
\text { Charateristic }\end{array}$ & -0.13 & 0.77 & .57 & 3.94 & 2.29 \\
\hline $\begin{array}{l}\text { AT3 -> Managerial } \\
\text { Charateristic }\end{array}$ & 0.24 & 1.56 & 76 & 7.56 & 2.38 \\
\hline $\begin{array}{l}\text { AT4 -> Managerial } \\
\text { Charateristic }\end{array}$ & 0 . & 0.70 & 0.79 & 7.05 & 2.53 \\
\hline $\begin{array}{l}\text { KT1 -> Managerial } \\
\text { Charateristic }\end{array}$ & 0.54 & 177 & 95 & 20.81 & 3.64 \\
\hline lagerial & 0.01 & 0.04 & .84 & 9.28 & 3.43 \\
\hline $\begin{array}{l}\text { KT3 -> Managerial } \\
\text { Charateristic }\end{array}$ & 0.11 & 0.81 & .74 & 7.89 & 2.06 \\
\hline \multicolumn{6}{|c|}{ NVIRONMENT } \\
\hline$\overline{\mathrm{G} 1}>\mathrm{Er}$ & 0.97 & 1.19 & 0.10 & 0.52 & 4.88 \\
\hline $2->E$ & -0.91 & 0.82 & -0.12 & 0.43 & 7.59 \\
\hline G3 -> Env & -0.55 & 0.66 & -0.02 & 0.10 & 7.25 \\
\hline G4 -> Environtment & 0.85 & 1.62 & 0.67 & 1.82 & 1.30 \\
\hline & 0.78 & 1.05 & & 1.61 & 6.17 \\
\hline ent & -0.63 & 088 & 0.19 & 0.94 & 5.48 \\
\hline nent & 0.21 & 0.48 & 4 & 1.13 & 3.39 \\
\hline \multicolumn{6}{|c|}{ ICT ADOPTION } \\
\hline$\overline{\Gamma 1}$ & 0.20 & 7.68 & . & 65 & 1.6 \\
\hline & & & & 26.48 & 3.17 \\
\hline & 0.22 & & 0.89 & 23.63 & 3.72 \\
\hline & 0.22 & 11.83 & 0.87 & $2 ., 19$ & 2.93 \\
\hline ICT5 <- ICT Adoption & 0.18 & 8.40 & 0.78 & 8.74 & 2.58 \\
\hline ICT6 <- ICT Adoption & 0.18 & 8.79 & 0.77 & 9.86 & 3.14 \\
\hline
\end{tabular}

\section{ICT Adoption}

Based on the using basic ICT adoption, around more 20\%, respondents utilize hand phone, computer/ laptop, and internet access. The most preferred adop- 
tion of ICT by the respondents for communication is email $(77 \%)$ followed by intranets $(30 \%)$. Whereas for the marketing of respondents would choose web page $(77 \%)$ rather than e-commerce $(18 \%)$.

\section{Model Measurement}

\section{Formative Measurement Model}

The concept of reliability and construct validity are not meaningful when employing the formative measurement model. The formative measurement model of subsequent analysis should be considered collinearity the indicator. Each indicator tolerance, VIF value has to range between $<3$ and $<10$. Table 1 indicated the all of the indicators have the VIF value less than 3 and 10, means not occur collinearity. The prior assessment should be testing each indicator's outer weight and outer loading. When indicator's outer weight is significant that the indicator keeps being retained. However, if an indicator weight is insignificant but the appropriate outer loading is significant, the indicators have to be retained. Furthermore, if outer weight and outer loading were insignificant, there is no empirical support to retain the indicators it should be dropped from the model. If the theorydriven conceptualization of the construct strongly supported retaining the indicators, it should be kept in the formative constructs. Based on Table 1, all indicators in the formative constructs have to be retained. Because there is indicator significant as outer weight, outer loading and supporting the theory-driven conceptualization (Afthanorhan, 2014).

\section{Structural Model}

\section{$R$-square}

$R$-square value for each endogenous variable is the predictive of power of the structural model. It is 0.25 (weak), 0.50 (moderate), 0.75 (strong). The prediction of the ICT adoption construct was explained at 70.45 percent variance by its relationship with technology, organization, managerial characteristic, and environment as shown on Table 2.

Table 2

$R$-Square Endogen Variable

\begin{tabular}{ccc}
\hline Variable & R-Square & Chin (1998) \\
\hline ICT Adoption & 0.7045 & Moderate model \\
\hline
\end{tabular}

\section{$Q$-square}

$Q$-square is a measure of predictive relevance based on the blindfolding technique. Table 3 indicated the endogenous construct of ICT adoption has a value greater than zero (0). It means the construct indicated good predictive relevance.

Table 3

$Q$-square

\begin{tabular}{lrrr}
\hline \multicolumn{1}{c}{ Total } & \multicolumn{1}{c}{ Sso } & \multicolumn{1}{c}{ Sse } & \multicolumn{1}{c}{ 1-Sse/Sso } \\
\hline Technology & 4818 & \multicolumn{3}{c}{3989.4945} & 0.172 \\
Organization & 1752 & 1101.9839 & 0.371 \\
Managerial & 1022 & 474.857 & 0.5354 \\
Characteristic & & 1193.0918 & -0.1674 \\
Environment & 1022 & 114.7241 & 0.5266 \\
ICT Adoption & 876 & 414 &
\end{tabular}

\section{Structural Path Coefficient}

The structural measurement model is shown in Table 4. It is observed that among hypotheses $H_{4}$ is not supported (insignificant $T$-values) while the hypotheses $H_{1}, H_{2}, H_{3}$ are supported (significant $T$ values).

Table 4

Structural Model for this research

\begin{tabular}{|c|c|c|}
\hline & $\begin{array}{c}\text { Observed } \\
\text { T-value }\end{array}$ & $\begin{array}{c}\text { Sig level } \\
\text { (two tailed) }\end{array}$ \\
\hline $\begin{array}{l}\text { Technology -> ICT } \\
\text { Adoption }\end{array}$ & 2.7587 & Sig \\
\hline $\begin{array}{l}\text { Organization -> ICT } \\
\text { Adoption }\end{array}$ & 2.5926 & Sig \\
\hline $\begin{array}{l}\text { Managerial Characteristic } \\
\text {-> ICT Adoption }\end{array}$ & 3.9507 & Sig \\
\hline $\begin{array}{l}\text { Environment -> ICT } \\
\text { Adoption }\end{array}$ & 1.0323 & Ns \\
\hline
\end{tabular}

The test relationship between construct indicates the construct affect the technology, managerial characteristic and organization provided positive effect to ICT adoption.

The first hypothesis found that the technology of an ICT adoption have a significant association with the use of ICT adoption. The results of this study found a significant relationship between technology and the adoption of ICT (see Table 4). According to Ramdani, Chevers and Williams (2013), context technology has a positive impact on the enterprise application (EA) consists of ERP (Enterprise Resource Planning), SCM (Supply Chain Management), CRM (Customer Relationship Management) and e-procurement system among northwest of England's SMEs.

The second hypothesis found that there was significant evidence to support this hypothesis, and indicated in the context of Indonesian SMEs. Similarly, the study of SMEs in northwest England states the organization has a positive influence on the adoption of enterprise application (EA) include ERP (Enterprise 
Resource Planning), CRM (Customer Relationship Management), SCM (Supply Chain Management) and e-procurement system (Ramdani et al., 2013). Several previous studies that support the result of the research hypotheses are Wang, $\mathrm{Li}, \mathrm{Li}$, and Zhang, (2016) said that organization factors with the support of top management, firm size, and technology competence influences adoption of MHRS (Mobile Hotel Reservation System) in hotel's Taiwan. Followed by a study Lin, (2014) revealed that the organization context with top management support and absorptive capacity are more likely to adopt e-SCM (electronic Supply Chain Management) in large Taiwanese firm. The organizational context in the form of openness of the corporate culture affects service co-production on IT Company Taiwan (Tsou \& Hsu, 2015). According to Cao, Jones, and Sheng, (2014) stated organizational context with the dimensions of organizational culture, organizational structure management support and financial commitments play an important role in adopting RFID (Radio Frequency Identification) for the healthcare industry in the Midwestern United State.

The third hypothesis found that the managerial characteristic have a significant relationship with the use of ICT adoption. Managerial characteristic in this study explain about people make to decision in SME's just like owner's and Chief Executive Officer (CEO) or top manager. According to VilasecaRequena, Torrent-Sellens, Meseguer-Artola and Rodríguez-Ardura, (2007) stated still lack evidence which managerial characteristics are directly influenced to the enterprise's decision to adopt e-commerce. This statement supported the result of this study.

The fourth hypothesis found there is insignificant relationship between environment and ICT adoption among Indonesian's SMEs. Environment is external factor from organizational what it could not control by organization. The result this study was insignificant between environmental with the adoption of ICT among Indonesia's SMEs. In contrast to research Ramdani et al. (2013) stated that there was a positive impact of environment on the adoption of the enterprise application (EA) on England's SMEs. In this study, the environment associated with the government and business partner. Government related to assistance and policies that encourage SMEs to use technology in their business, especially ICT business partner is composed of suppliers and customers related to their business activities It is based on the Tornatzky and Fleischer's (1990) theory that measures the environmental effects of the consumers, trading partners, competition, and government.

\section{Conclusion}

This study examined the factor influence the use of ICT adoption and impact to use ICT adoption. The 146 SME in Indonesia has been the respondents with questionnaire surveys and the analysis has used SEM/SmartPLS. Three of four hypotheses were significant influence to ICT adoption.

Most respondents use ICT at the basic level such as mobile phones, personal computer (PCs), and internet access. Therefore, the average level of education of the respondents is bachelor, and then the respondent receives only innovation but not necessarily to use. Respondents who an owner, director in SME and they are made decision to using ICT adoption. It can be concluded the environment was not affect ICT adoption in Indonesian SMEs.

\section{Implication}

The findings carry theoretical implications for the ICT adoption literature Moreover, this research allows managers to recognize better how to manage organization the efficiency and effectively and to expand uses ICT adoption on company with the aim of identifying organization performance.

\section{References}

Afthanorhan, W. M. A. B. W. (2014). Hierarchical component using reflective-formative measurement model in partial least square structural equation modeling (PIS-SEM). International Journal of Mathematics and Statistics Invention (IJMSI), 2(2), 55-71.

Ahmad, S. Z., Bakar, A. A., Faziharudean, T. M., \& Zaki, K. A. M. (2015). An empirical study of factors affecting e- commerce adoption among small- and medium- sized enterprises in a developing country: Evidence from Malaysia. Information Technology for Development, 21(4), 555-571.

Alam, S. S. \& Noor, M. K. M. (2009). ICT adoption in small and medium enterprises: An empirical evidence of service sectors in Malaysia. International Journal of Business and Management, 4(2), 112-125.

Al-Qirim, N. (2007). The adoption of e-commerce communications and applications technologies in small businesses in New Zealand. Electronic Commerce Research and Applications, 6, 462473.

Awa, H. O., Ojiabo, O. U., \& Emecheta, B. C. (2015). Integrating TAM, TPB and TOE frameworks and expanding their characteristic constructs for e-commerce adoption by SMEs. Journal of 
Science \& Technology Policy Management, 6(1), 76-94.

Azadegan, A. \& Teich, J. (2010). Effective benchmarking of innovation adoptions: A theoretical framework for e-procurement technologies. Benchmarking: An International Journal, 17(4), 472-490.

Bayo-Moriones, A., Billon, M., \& Lera-López, F. (2013). Perceived performance effects of ICT in manufacturing SMEs. Industrial Management \& Data Systems, 113(1), 117-135.

Bayo-Moriones, A. \& Lera-López, F. (2007). A firmlevel analysis of determinants of ICT adoption in Spain. Technovation, 27(6-7), 352-366.

Chairoel, L., Widyarto, S., \& Pujani, V. (2015). ICT Adoption in affecting organizational performance among Indonesian SMEs. The International Technology Management Review, 5(2), 82-93.

Chong, S. (2008). Success in electronic commerce implementation: A cross-country study of small and medium-sized enterprises. Journal of Enterprise Information Management, 21(5), 468-492.

Delone, W. H. \& Mclean, E. R. (2004). Measuring ecommerce success: Applying the DeLone \& McLean information systems success model. International Journal of Electronic Commerce, 9(1), 31-47.

Gangwar, H., Date, H., \& Ramaswamy, R. (2015). Understanding determinants of cloud computing adoption using an integrated TAM-TOE model. Journal of Enterprise Information Management, 28(1), 107-130.

Gemino, A., Mackay, N., \& Reich, B. H. (2006). Executive decisions about website adoption in small and medium-sized enterprises. Journal of Information Technology Management, 17(1), 35-50.

Ghobakhloo, M., Amado, J. B., \& Arias-Aranda, D. (2011a). Reasons for information technology adoption and sophistication within manufacturing smes. POMS 22 $2^{\text {nd }}$ Annual Conference: Operations Management: The enabling link Reno, Nevada, U.S.A.

(2011b). Adoption of e-commerce applications in SMEs. Industrial Management \& Data Systems, 111(8), 1238-1269.

Ghobakhloo, M., Hong, T. S., Sabouri, M. S., \& Zulkifli, N. (2011). Information technology adoption in small and medium-sized enterprises: An appraisal of two decades literature. Interdisciplinary Journal of Research in Business, 1(July), 53-80.
Golding, P., Donaldson, O., Tennant, V., \& Black, K. (2008). An analysis of factors affecting the adoption of ICT by MSMEs in rural and urban Jamaica. ECIS 2008 Proceedings Website. Jonkoping International Business School Jonkoping University.

Huy, L. E. V, Rowe, F., \& Truex, D. (2012). An empirical study of determinants of e-commerce adoption in smes in Vietnam an economy in transition. Journal of Global Information Management (JGIM), 20(3), 23-54.

Iacovou, C. L., Benbasat, I., \& Dexter, A. S. (1995). Electronic data interchange and small organizations: Adoption and impact of technology. MIS Quarterly, 19(4), 465-485.

Irefin, I., Abdul-Azeez, I. A., \& Tijani, A. A. (2012). An investigative study of the factors affecting the adoption of information and communication technology in small medium scale enterprise in Nigeria. Australian Journal of Business and Management Research, 2(2), 1-9.

Jeon, B. N., Han, K. S., \& Lee, M. J. (2006). Determining factors for the adoption of e-business: the case of SMEs in Korea. Applied Economics Journal, 38(16), 1905-1916.

Kabongo, J. D. \& Okpara, J. O. (2014). ICT possession among Congolese smes: An exploratory study. Journal of Small Business and Enterprise Development, 21(2), 313-326.

Kapurubandara, M. (2009). A Framework to e-transform SMEs in developing countries. EJISDC, 39(3), 1-24.

Looi, H. C. (2005). E-commerce adoption in Brunei Darussalam: A quantitative analysis of factors influencing its adoption. Communications of the Association for Information Systems, 15(3), 6181.

Maryeni, Y. Y., Govindaraju, R., Prihartono, B., \& Sudirman, I. (2014). E-commerce adoption by Indonesian SMEs. Australian Journal of Basic \& Applied Sciences, 8(14), 45-49.

Muafi \& Roostika, R. (2014). Organizational performance and competitive advantage determinants of creative smes. European Journal of Economics And Management, 1(2), 7-25.

Ndiege, J. R. A., Herselman, M. E., \& Flowerday, S. V. (2012). Information and communication technologies within small and medium enterprises in developing economies. African Journal of Business Management, 6(10), 35763582 .

Ramdani, B., Chevers, D., \& Williams, D. A. (2013). Smes' adoption of enterprise applications: A technology-organisation-environment model. 
Journal of Small Business and Enterprise Development, 20(4), 735-753.

Rogers, E. M. (1995) Diffusion of innovations, Fourth Edition. New York: The Free Press.

Tan, K. S., Chong, S. C., Lin, B., \& Eze, U. C. (2010). Internet-based ict adoption among smes: Demographic versus benefits, barriers, and adoption intention. Journal of Enterprise Information Management, 23(1), 27-55.

Tigre, P. B. (2003). Brazil in the age of electronic commerce. The Information Society Journal, $19,33-43$.
Thong, J. Y. L. \& Yap, C. S. (1995). CEO characteristics, organizational characteristics and information technology adoption in small businesses. Omega Journal, 23(4), 429-442.

Tornatzky, L. \& Fleischer, M. (1990). The process of technology innovation. Lexington, Mass: Lexington Books.

Vilaseca-Requena, J., Torrent-Sellens, J., MeseguerArtola, A., \& Rodriguez-Ardura, I. (2007). An integrated model of the adoption and extent of e-commerce in firms. International Advance in Economics Research Journal, 13(2), 222-241. 